\title{
COGNITIVE INHIBITION TESTED BY STROOP COLOUR WORD TASK IN EFL TEACHERS AS SUCCESSIVE BILINGUALS
}

UDC $81^{\prime} 246.2$

\author{
Ivana Šorgić ${ }^{1}$, Marija Nešić ${ }^{2}$ \\ ${ }^{1}$ University of Niš, Faculty of Philosophy, Foreign Language Center, Niš, Serbia, \\ ${ }^{2}$ Singidunum University, Center in Niš, Niš, Serbia
}

\begin{abstract}
This paper is a partial replication study of the one done by Heidlmayr et al. (2014), and concerns the effect of second language use on inhibitory control/cognitive inhibition analysed by means of a Stroop Colour Word task in both L1 and L2, i.e. Serbian and English. Our aim was to test the starting hypothesis of the original research which states that the frequency of $L 2$ use in successive bilinguals has an impact on their inhibitory control mechanism. The bilingual subjects asked to take part in the study by doing the bilingual version of the test are all EFL teachers at the Faculty of Philosophy in Nis. Their use of L2 is akin to that of bilinguals living in an L2 environment (such as those from the original research), in the sense that they communicate daily using $L 2$ and cover a wide variety of topics with their students. Our monolingual subjects, who served as control group, were randomly chosen from the same age group as bilinguals (older adults). They were asked to do only the L1 version of the test. The purpose of this small-scale research was to give a contribution to the ever-growing debate concerning the cognitive advantages of bilingualism.
\end{abstract}

Key words: Stroop Colour Word task, cognitive inhibition, successive bilingualism, Serbian, English

\section{INTRODUCTION}

Even though the majority of the world population is bilingual (or multilingual), the phenomenon of bilingualism has proven extremely difficult to define with precision. Many authors, therefore, revert to describing it along several overlapping dimensions, including linguistic ability, use and balance of the languages, age of acquisition, development, culture, context, etc. (Baker, 2011: 3). What most authors agree on is that bilingualism should be

Submitted September $9^{\text {th }} 2017$, accepted for publication November $20^{\text {th }}, 2017$

Corresponding author: Ivana Šorgić

Faculty of Philosophy, Ćirila i Metodija 2, 18000 Niš, Serbia

E-mail: ivana.vlajkovic@filfak.ni.ac.rs 
viewed as a continuum, rather than a clearly delineated category. According to BadzakovaTrajkov (2008), bilinguals are capable of communicating in both languages without difficulty, and their language switching represents constant negotiation between the two lexical choices, from which they are supposed to retrieve meaning. Moreover, not only do proficient bilinguals switch languages effortlessly, but they can do so without intrusions from the other language or even with code-switching, i.e. introducing words from the other language into the current language of use. In order to be able to do so, they require a cognitive control mechanism, which, among other things, is responsible for directing thought and action, filtering out the irrelevant information and inhibiting inappropriate responses or thoughts.

In popular culture, the issue of whether bilingualism has positive effects on cognitive abilities in both children and adults, due to their everyday language switching, is a widely discussed one. Various studies have shown that the monitoring or coordination of the two language systems actually enhances "performance in bilinguals on tasks that rely on executive functions like selective attention, cognitive flexibility or inhibitory control" (BadzakovaTrajkov, 2008). However, there have also been studies the results of which failed to prove this.

The idea for this research came from a paper by Heidlmayr et al. (published in 2014), and was meant to be a small contribution to this ongoing debate. The fact that both authors are faculty members at universities where L2 is used on a daily basis greatly facilitated the partial replication of the testing process. The subsequent paragraphs will provide a brief literature review, as well as the description of the Stroop colour word task.

\subsection{Literature review}

In order to gain a better understanding of the potential cognitive advantages of bilingualism, we should begin with a short overview of the topic in the relevant literature, as well as with the introduction of the key concepts it encompasses. Firstly, the concept of 'cognitive ability' mentioned earlier has to be narrowed down to what is referred to as cognitive inhibition. Cognitive inhibition, or the inhibition of dominant responses, is one of the three main executive functions involved in the ability to switch languages and converse in one target language in bilingual and multilingual individuals. The other two include the shifting of mental sets (or 'shifting' for short) and the monitoring and updating of information in working memory ('updating'). Miyake et al. (2000: 50) write that "research on executive functions has historical roots in neuropsychological studies of patients with frontal lobe damage" and that "cognitive psychology has made considerable progress over the last few decades and has developed sophisticated theories and models about specific cognitive domains or processes." However, they say "despite this headway, there still remain a number of theoretical issues or phenomena about which little can be said." The main problem with studying cognitive inhibition as a psychological phenomenon is the fact that it "can only be observed indirectly, using experimental paradigms designed to examine many various executive processes" (Heidlmayr, 2014: 632). Some of the most common experimental tasks used for this purpose include: the Wisconsin Card Sorting Test (WCST), Tower of Hanoi (TOH), random number generation (RNG), the Stroop task, the Simon task, etc. Since Heidlmayr et al. focused on the role of cognitive inhibition as related to language, they opted for the Stroop colour word task, which we replicated.

The aim of both the original paper and our replicated study was to "examine whether the efficiency of cognitive inhibition among bilinguals is influenced by the need to switch languages in their daily lives" (Heidlmayr, 2014: 631). Literature indeed shows that executive 
functions can be trained and improved by performing different activities, especially those which require attention and memorisation, such as playing a musical instrument, playing video games or engaging in physical activity requiring high coordination. However, the most important role in increasing the executive function is played by the use of multiple languages. In a study from 2009, Bialystok and DePape showed that both individuals with extensive musical experience and bilinguals outperformed monolinguals in certain cognitive non-verbal tasks. Furthermore, Costa, Hernández \& Sebastián-Gallés (2008) proved that bilinguals had advantage over monolinguals when it comes to tasks which depend upon attentional networks.

Bilinguals solved the tasks considerably faster, and were better at resolving conflicting information. Moreover, even studies which tested trilinguals and multilinguals revealed results comparable to those of bilinguals. Although this research is scarce, there is some evidence that cross-language similarity across colour words, in terms of orthographic/phonological overlap between the colour word translations and script, influences between-language Stroop interference, as well as facilitation (Van Heuven et al. 2011). Still, not all findings conclude that there are cognitive advantages to being bilingual or multilingual. In a study from 2008, Carlson and Meltzoff worked with kindergarten children who were divided into three groups: native bilinguals (English-Spanish), monolinguals, and English children enrolled in secondlanguage immersion kindergarten. They showed advantages in some aspects of executive functioning, but not in all of them. Moreover, in three studies comparing bilinguals to monolinguals on 19 indicators of executive processing, Paap and Greenberg (2013) report no bilingual advantages and one bilingual disadvantage. Hilchey and Klein (2011) reviewed 31 experiments using non-verbal interference tasks (e.g., Simon or flanker tasks) and concluded that evidence for a bilingual advantage in inhibitory control in both children and young adults is rare and that the collective evidence "... is simply inconsistent with the proposal that bilingualism has a general positive effect on inhibitory control processes" (Paap and Sawi 2014).

In as early as 1980 (and again in 1987), "Kessler and Quinn examined the effects of bilingualism on creativity and scientific problem-solving. They hypothesized that relevant aspects of a (non-verbal) problem may become more salient to bilingual children because their experiences with two languages and cultures would enable them to incorporate different perspectives to the solution" (Bialystok 2001: 204).

\subsection{The Stroop task}

While different studies focused on studying increased executive function in bilinguals by means of the aforementioned non-verbal tasks (The Tower of Hanoi, the Simon task, etc.), researchers from the field of linguistics focused on the Stroop task, which is verbal. Evidence from cross-linguistic Stroop task suggests that even though bilinguals and multilinguals manage to keep their languages separate when producing sentences, the language centres may well be both or all active at the same time. As for the task itself, Bialystok (2001: 40) writes that: "The Stroop effect was first introduced to the cognitive psychology research field in 1935 (Stroop, 1935). The Stroop effect, also called the interference effect, is easily demonstrated when subjects are asked to name the colour of a printed colour word that is different to the target colour (e.g., RED written in green). This condition leads to an increase in the number of errors and the time taken to respond compared to a condition where the colour word is consistent with the target colour (e.g., RED written in red) or a neutral word (e.g., JUMP) is presented instead of a colour word. In bilingual versions of the Stroop task the word name can be printed in the 
subjects' first language, with the response in the second language, or vice versa (cross-language Stroop task). A main finding of cross-language Stroop experiments is that Stroop interference occurs both within and between languages, but the within-language interference is stronger (e.g., Preston \& Lambert, 1969). This suggests that the switch between languages is not complete, and that both processing systems remain active during language processing." Heidlmayr et al. employed the Stroop task for the purpose of studying inhibitory control in bilinguals, because in this task, decisions must be based on task-relevant information in the face of distracting information. Indeed, 'two conflicting mental representations are active, each associated with a different response, and attention must be paid to only relevant clues'. [...] Since word reading is more automatic than colour naming, executive control is required to override the tendency to respond on the basis of the word rather than the ink colour" (Heidlmayr 2014:633). If being bilingual enhances cognitive abilities, more precisely cognitive control, there should be a smaller interference effect in bilinguals compared to monolinguals, as measured by the Stroop task. In other words, bilinguals are expected to perform better than monolinguals in incongruent examples (Stroop Interference), and they should require less time in congruent examples (Stroop Facilitation). Following in their footsteps, but from a slightly different perspective, we attempted to study bilingualism through inhibitory control.

\section{METHODOLOGY}

The subsequent three paragraphs will describe how the research was designed and carried out. They will provide a detailed account of participants, stimuli and procedure, as well as compare them to the original research. One of the main difference between the original and replicated research concerns the choice of participants, in our case EFL teachers, who are not traditionally chosen as subjects for research in bilingualism.

\subsection{Participants}

In the original research "Sixty-five right-handed (Edinburgh Handedness Inventory) participants were recruited. Among them, 34 were successive French (L1) - German (L2) bilinguals living either in France $(n=17)$ or in Germany $(n=17)$, and 31 were French monolingual individuals. Sixteen successive French (L1) - German (L2) bilinguals (12 female) of an average age of 26.8 years were tested in their L1 environment (Paris, France) and seventeen successive French (L1) - German (L2) bilinguals (15 female) of an average age of 32.4 years were tested in their L2 environment (Hamburg, Germany, or Vienna, Austria). They were all late learners of their L2, German, which they had started to study by the age of 10 at secondary school in France". As for our research, the total of 40 subjects was recruited, 20 successive Serbian (L1) - English (L2) bilinguals and 20 Serbian monolinguals, all living in their L1 environment, Serbia. The bilinguals, 5 of whom were male and 15 female, are all EFL teachers employed at the Faculty of Philosophy in Niš with a minimum 5-year work experience. This might seem an unusual choice of subjects, but EFL teachers fit almost any definition of bilingualism available in literature. Grosjean (2010: 4) for example, gives the broadest definition of bilinguals as "those who use two or more languages (or dialects) in their everyday lives". Most definitions focus solely on linguistic competence, but still range from defining bilinguals as highly proficient in both L1 and L2 to accepting minimal proficiency in L2. More modern approaches, on the other hand, insist on the inclusion of non-linguistic criteria as well, 
and viewing language as a tool which serves many different social and psychological functions (Hamers and Blanc, 2013: 8). An individual can be considered bilingual regardless of whether they acquired L2 early or late, whether they live in the L1 or L2 environment, whether they use L2 because it is spoken by an entire community, or limit their use to a small group, or even just their family.

Since finding bilinguals of similar age and equal social, economic, and educational status would be extremely difficult in a relatively small community like ours, we opted for testing this very specific group of individuals. The criteria for their inclusion in the study was at least 5 years of teaching at the university level (which at the same time guaranteed their proficiency in English), a setting where L2 is used on a daily basis to discuss various complex topics. The fact that our selected group of bilinguals also differs from what is traditionally considered a bilingual individual in that they study language professionally was irrelevant in this particular setting, as linguistic knowledge wouldn't factor in solving the Stroop task. The study was limited to L1 environment, unlike the original research. For bilinguals, mean age was $34.0 \pm 6.05$, and for monolinguals $36.2 \pm 6.2$. Similarly, all subjects were late learners of L2, which they had started to study between the age of 10 and 12 . As for the monolingual individuals, who are always more difficult to find, we focused on subjects who did not study English throughout their education (but mostly Russian, which used to be common as a foreign language course in both elementary and secondary education in Serbia), and whose knowledge of the foreign language was such that they were unable to form even a simple sentence, and understood a handful of words at most. According to their reports, they have never used the language they learned in elementary/secondary school, in the classroom or outside of it. Furthermore, to match the bilingual group in their education, we chose only individuals with a university or postgraduate degree. Additionally, we also focused on a secondary set of criteria, such as: socio-economic status, playing sports, which require high bi-manual coordination, playing a musical instrument or video games, which, as it had been reported in some research, may have some influence on the results. On the whole, our monolinguals and bilinguals did not differ significantly on either of the aforementioned factors.

\subsection{Stimuli}

As in the original study, an adapted version of the Stroop task was used in the experiment. The participants were presented with three different stimuli (congruent, incongruent, neutral), which appeared individually in the centre of the screen, against a black background, written in capitals, in "Calibri", font size 48. Their task was to identify the print colour and respond manually. In the congruent condition, the meaning of the colour word matched the print colour, in the incongruent condition, these two differed and, finally, in the neutral condition, there were non-colour words, which appeared randomly on the screen in the four colours. Depending on the condition, the stimuli were either colour words (e.g. "green", "blue", etc.), or non-colour words (e.g. "god", "eye", etc.). The colour words we chose for L1, Serbian, were: CRVENO, PLAVO, CRNO, ZELENO and in the L2, English, the four corresponding words: RED, BLUE, BLACK, GREEN. The words used as neutral words in L1, Serbian, and their translation equivalents in L2, English, were: OKO "eye", NOS "nose", BOG "god", SKUP "set". The original research used the neutral stimuli as the control condition because "stimuli did not include colour information", which could cause interference in the Colour Word task (Heidlmayr, 2014). 


\subsection{Procedure}

The Strop Colour Word task was created using the Visual Studio 2002 program and the $\mathrm{C \#}$ programming language. Before running the experiment, each participant was given oral instructions and, when it comes to bilinguals, they were engaged in a five-minute conversation in English so as to activate their L2 centre in the brain. Seated in front of a laptop, with both hands on the keyboard, the participants were instructed to indicate as quickly and as correctly as possible the print colour of the stimulus word by pressing the correct response button on the keyboard.

In order to facilitate the task, the colours were indicated throughout the experiment at the bottom of the screen. As in the original research, the response keys were D, F, J and K, since they allow the usual position of the hands on the keyboard. Each stimulus word was preceded by a fixation cross in the centre of the screen, which stayed there between $500 \mathrm{~ms}$ and $1000 \mathrm{~ms}$ (equally but randomly distributed among the stimuli), so as to prevent systematic expectancy by the participants.

The stimulus word which followed stayed on the screen maximally for $1500 \mathrm{~ms}$, or until one of the four response keys, corresponding to the four colours, was pressed. If there was no response, after $1500 \mathrm{~ms}$, the answer was noted as wrong. The inter-stimulus interval (ISI) was the same as in the original research $(500 \mathrm{~ms})$. The response time (RT) was measured from the moment the stimulus appeared on the screen until the moment a response key was pressed. Two practice blocks of 20 trials (in the original research the number of trials per block was 40) were presented before the six experimental blocks to each participant, so that the participant could get used to the colour-key correspondences. For the monolinguals, both practice blocks consisted of words in Serbian, whereas, for the bilinguals, the first block was in L1, i.e. Serbian, and the second block in L2, i.e. English.

Immediately upon completing the practice block, the participants were given feedback on the percentage of correct answers. They could not move on to the experimental phase unless the accuracy in the practice blocks was less than $80 \%$, in which case the practice blocks were repeated. After reaching $80 \%$ of correct answers, the participants were tested in six blocks each containing 36 trials (in the original research the number of trials per block was 72). In each block, there were 12 congruent stimuli, 12 incongruent stimuli and 12 neutral stimuli, presented randomly, but with the response colours being counterbalanced, yet constant for every participant. Therefore, similar to the original research, there were certain constraints for the random choice, such as: the first stimulus of each block was a neutral one; then, no word and no print colour were repeated immediately; finally, no more than three words of the same experimental condition were presented in succession. Furthermore, for bilingual participants no more than two blocks of one language were presented in succession. The participants could take a short pause in case they needed one before they moved on to the next block.

\section{RESULTS}

The data obtained via the testing process was exported directly into Excel sheets from which it was later copied and analysed using SPSS software, version 20.0 (IBM SPSS Inc.). The values were presented as mean \pm standard deviation. Statistical analysis was performed using one-way analysis of variance - ANOVA procedure to test the hypothesis that the means of two or more groups are not significantly different. The one-way 
ANOVA procedure allowed for the comparison of every mean between different groups, a method known as pairwise multiple comparisons using Bonferroni post hoc test. $\mathrm{P}$ values of less than 0.05 were considered significant.

The first part of the analysis focused on error rates and response times, which is illustrated in Table 1. As for the error analysis, even though the monolingual group made more mistakes, the differences between the two groups did not reach statistical significance for all three types of stimuli (congruent, incongruent and neutral). The situation is slightly different when it comes to averaged response times, where we can clearly see from Table 1 that bilinguals had an advantage over monolinguals, i.e. that they displayed significantly shorter response times in congruent, incongruent, and neutral stimuli. As expected, both groups needed most time to respond to incongruent stimuli, which was interestingly enough, not mirrored in error rates, where we can see an equal number of errors for both congruent and incongruent conditions in the monolingual group, and more errors made for neutral than incongruent conditions in the bilingual group. These results are different from the ones obtained in the original study, where the bilingual group had a clear advantage over the monolingual individuals in both error rates and response time, for all three types of stimuli, and where both groups displayed higher error rates and longer response time for the incongruent stimuli. The only segment of our results consistent with the original study is that neutral stimuli yielded shorter response times than congruent stimuli in both groups.

Table 1 Error rates and response times

\begin{tabular}{lcrrr}
\hline Analysis & Condition & $\begin{array}{c}\text { Monolinguals } \\
(\mathrm{n}=15)\end{array}$ & $\begin{array}{c}\text { Bilinguals } \\
(\mathrm{n}=15)\end{array}$ & ANOVA ( F,p) \\
\hline ERR & Congruent & $2.27 \pm 4.02$ & $1.66 \pm 1.59$ & $\mathrm{~F}=0.272, \mathrm{p}=0.606$ \\
$(\%)$ & Incongruent & $2.27 \pm 3.30$ & $1.96 \pm 2.25$ & $\mathrm{~F}=0.085, \mathrm{p}=2.25$ \\
& Neutral & $2.12 \pm 3.15$ & $2.27 \pm 2.97$ & $\mathrm{~F}=0.018, \mathrm{p}=0.893$ \\
\hline RT & Congruent & $681.27 \pm 95.34$ & $611.34 \pm 86.37$ & $\mathrm{~F}=4.43, \mathrm{p}<0.05$ \\
$(\mathrm{~ms})$ & Incongruent & $750.69 \pm 122.54$ & $651.04 \pm 92.56$ & $\mathrm{~F}=6.315, \mathrm{p}<0.05$ \\
& Neutral & $714.92 \pm 93.77$ & $625.20 \pm 98.03$ & $\mathrm{~F}=6.560, \mathrm{p}<0.05$ \\
\hline
\end{tabular}

However, when the three effects were calculated (Stroop, Inhibition, and Facilitation), the bilngual advantage seemed to disappear, which can be seen in Table 2 and Figure 1 . The three effects are calculated by subtracting congruent from incongruent response time, neutral from incongruent, and neutral from congruent, respectively. As we can see from the table, the size of all three effects - Stroop, Inhibition, and Facilitation is larger in the monolingual group than in the bilingual one, even though it reaches statistical significance only in the last category. The difference between the Inhibition and Facilitation effects was not significant (35.76 vs. 33.65 in the monolingual group, and a slightly increased difference in the bilingual group: 25.83 vs. 13.86), as was the case in the original study. As for the Stroop effect, which is usually mirrored by the Inhibition effect, the results are consistent in both studies, and show that bilinguals demonstrated smaller size effects in comparison to monolinguals. In our case, the Stroop effect was $69.41 \mathrm{~ms}$ in the monolingual group, compared with $39.70 \mathrm{~ms}$ in the bilingual group. The Inhibition effect had slightly lower values, amounting to $35.76 \mathrm{~ms}$ in monolinguals, and $25.83 \mathrm{~ms}$ in bilinguals. Even though the values are very similar to those obtained in the original study, where e.g. the Stroop effect was $62.1 \mathrm{~ms}$ for monolinguals, and $43.3 \mathrm{~ms}$ for bilinguals, they did not reach statistical significance in our study. This is arguably due to the relatively small sample in our study. 
Table 2 Mean values $( \pm \mathrm{SD})$ of effects in the study groups

\begin{tabular}{llcrrrr}
\hline \multirow{2}{*}{ Stroop } & & $\mathrm{N}$ & Mean & Std. Deviation & $\mathrm{F}$ & $\mathrm{p}$ \\
& Monolingual & 15 & 69.41 & 48.69 & 2.505 & $\mathrm{~ns}$ \\
& Bilingual & 15 & 39.70 & 54.00 & & \\
\multirow{2}{*}{ Inhibition } & Monolingual & 15 & 35.76 & 40.92 & 0.418 & $\mathrm{~ns}$ \\
& Bilingual & 15 & 25.83 & 43.21 & & \\
\hline \multirow{2}{*}{ Facilitation } & Monolingual & 15 & 33.65 & 21.94 & 4.336 & $<0.05$ \\
& Bilingual & 15 & 13.86 & 29.53 & & \\
\hline
\end{tabular}

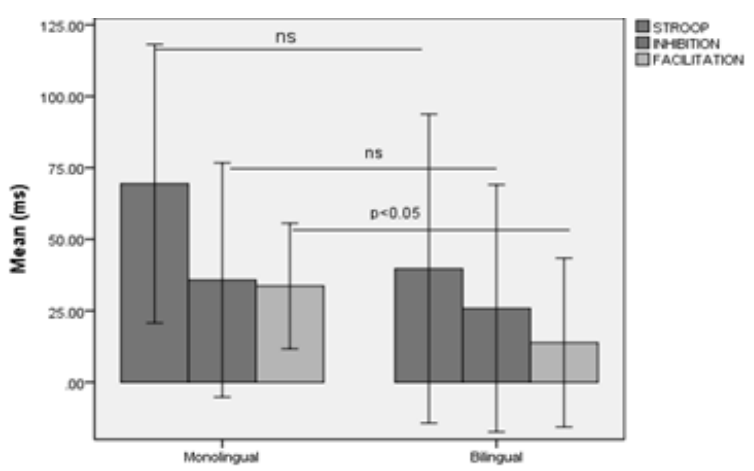

Fig. 1 Mean effect differences between the study groups

\section{DISCUSSION}

In this paper, we expected to obtain results similar to the original research done by Heidlmayr et al. (2014), which demonstrated cognitive advantage in bilinguals. However, it should be noted once again that literature is full of conflicting findings, from those which support bilingual advantage, to those which claim there is none and finally those which point to cognitive disadvantage. Some studies from the last category e.g. reported significantly longer response times in bilinguals in comparison to monolinguals. One such example is a study which attempted to examine the neurofunctional mechanisms of linguistic comprehension in monolinguals and bilinguals, where the authors concluded: "In general, the bilinguals turned out to be slower than the monolinguals in responding to linguistic stimuli, regardless of the language" (Proverbio, Cok, \& Zani, 2002).

Similarly, analysing within and between language interference using the Stroop Task, as well as the impact of language proficiency and age of acquisition of the second language on the Stroop Task scores, Roselli et al. also concluded: "Comparisons of Spanish-English bilinguals with both monolingual groups in the three conditions of the ST showed no significant differences except for the English colour naming condition in which the bilinguals' performance was significantly slower than the English monolinguals" (Roselli et al., 2002).

Furthermore, the study done by Okuniewska in 2007 did not confirm the hypothesis of a greater advantage in interference in more proficient late bilinguals, although it was expected that the participants who were late bilinguals, and whose proficiency in L2 was high due to frequent and everyday use of language, would show that they had developed and trained a cognitive inhibitory mechanism at least to such a degree which provides 
them with a significant advantage in dealing with Stroop interference, they did not, either in between-language condition or within-language condition. The author concluded that "there was no significant difference between Gr.T and Gr.L performance on withinlanguage condition (learners were even slightly faster than teachers)“", Gr.T standing for the more proficient bilinguals, and Gr.L for less trained group of learners (Okuniewska, 2007). Even in cases when smaller interference effect for bilinguals compared to monolinguals was noticed, it was usually not statistically significant, or, if the participants were young adults, it was ascribed to the fact that they are all (both monolinguals and bilinguals) skilled computer users, used to responding quickly to visual stimuli.

\section{CONCLUSION}

To conclude, we shall once again restate what has been said so far. Firstly, the aim of this paper was to examine the potential cognitive advantage of bilingualism by studying one of the three main executive functions, i.e. inhibitory control. The starting point was the hypothesis that bilinguals have a better control over inhibitory mechanisms when compared to monolinguals due to the frequency of L2 use and the alternate use of two languages in their daily lives. The results obtained in the study, which show generally shorter averaged response times in bilinguals for all three types of stimuli (congruent, incongruent, and neutral) might suggest that this group of individuals has a better capacity for inhibiting unnecessary or distracting information in tasks involving the resolution of conflicts. In other words, "this reinforces the idea that activities such as multiple language use are most likely to cause an improvement of the executive functions..." (Diamond, 2011).

Findings from the manual version of the Stroop task we employed indicated smaller Stroop and Interference effects for the bilingual group in both languages compared to the monolingual group. These results can be interpreted as a positive effect of bilingualism in late and proficient bilinguals.

However, even though our results may point to cognitive advantages of bilingualism when taken in isolation, the calculation of the three effects, the Stroop, Inhibition and Facilitation did not yield statistically significant differences between monolingual and bilingual individuals. Given that this was a small-scale research, it can be said that the size of the sample most likely affected the study results. Therefore, further research is needed to definitely confirm whether the daily use of L2 could lead to improvements in executive functions.

\section{REFERENCES}

Badzakova-Trajkov. G. 2008. A behavioural and functional imaging investigation of Stroop task performance in late proficient bilinguals, PhD thesis, Department of Psychology, The University of Auckland.

Baker, C., 2011. Foundations of bilingual education and bilingualism (Vol. 79). Multilingual matters.

Bialystok, E. 2001. Bilingualism in development: Language, literacy, and cognition. Cambridge, UK: Cambridge University Press.

Diamond, A. 2011. Biological and social influences on cognitive control processes dependent on prefrontal cortex. (http://www.ncbi.nlm.nih.gov/pmc/articles/PMC4103914/)

Grosjean, F. 2010. Bilingual: Life and Reality. Cambridge, Mass: Harvard University Press.

Hamers, J. F., Blanc, M. 2013. Bilinguality and Bilingualism. Cambridge University Press. 
Heidlmayr, K. 2014. "Successive bilingualism and executive functions: The effect of second language use on inhibitory control in a behavioural Stroop Colour Word task". Bilingualism: Language and Cognition, 17, pp 630-645 (http://journals.cambridge.org/abstract_S1366728913000539)

Kessler, C., Quinn, M.E. 1980. "Positive Effects of Bilingualism on Science Problem-Solving Abilities.” In Current Issues in Bilingual Education, ed: J.E. Alatis. Washington, DC: Georgetown University Press, pp 295-308.

Miyake, A., Friedman, N. P., Emerson, M. J., Witzki, A. H., Howerter, A., \& Wager, T. D. 2000. The unity and diversity of executive functions and their contributions to complex "Frontal Lobe" tasks: A latent variable analysis. Cognitive Psychology, 41, 49-100.

Okuniewska, H. 2007. "Impact of Second Language Proficiency on the Bilingual Polish-English Stroop Task". Psychology of Language and Communication, 11 (2), 49-63.

Paap, K.R, Sawi, O. 2014. "Bilingual advantages in executive functioning: problems in convergent validity, discriminant validity, and the identification of the theoretical constructs". Frontiers in Psychology, 5:962.

Proverbio, A. M., Cok, B., \& Zani, A. 2002. "Electrophysiological measures of language processing in bilinguals". Journal of Cognitive Neuroscience, 14 (7), 994-1017.

Rosselli, M., Ardila, A., Santisi, M. N., Arecco, M. d. R., Salvatierra, J., Conde, A., et al. 2002. "Stroop effect in Spanish-English bilinguals". Journal of the International Neuropsychological Society, 8(6), 819-827.

Van Heuven, W.J.B., K. Conklin, E.L. Coderre, T. Guo and T. Dijkstra (2011). "The influence of crosslanguage similarity on within- and between-language Stroop effects in trilinguals". Frontiers in Psychology

\section{KOGNITIVNA INHIBICIJA KOD ESL NASTAVNIKA KAO SUKCESIVNIH BILINGVISTA TESTIRANA STRUPOVIM TESTOM SA REČIMA U BOJI}

Ovaj rad predstavlja delimičnu repliku istraživanja koje su sproveli Hajdlmajr i saradnici 2014. godine $i$ bavi se uticajem koji upotreba drugog jezika ima na mehanizam inhibitorne kontrolel kognitivne inhibicije. Za testiranje je korišćen Strupov test sa rečima u boji, na srpskom i engleskom jeziku. Cilj istraživanja bio je da preispita polaznu hipotezu izvorne studije, koja kaže da frekventnost upotrebe drugog jezika kod sukcesivnih bilingvista utiče na njihov mehanizam inhibitorne kontrole. Bilingvalni ispitanici koje smo zamolili da učestvuju u istraživanju tako što će uraditi Strupov test i na srpskom i na engleskom jeziku su svi profesori engleskog jezika (ESL) na Filozofskom fakultetu u Nišu. Njihova upotreba drugog jezika slična je kao kod bilingvista koji žive na govornom području svog drugog jezika (kakvi su ispitanici u izvornom istraživanju) po tome što drugi jezik koriste svakodnevno i za širok spektar tematskih jedinica. Sa druge strane, jednojezični ispitanici, koji su služili kao kontrolna grupa, nasumično su odabrani u okviru iste starosne grupe kojoj su pripadali $i$ bilingvisti. Oni su radili samo jednojezičnu verziju testa. Svrha ovog malog istraživanja bila je da se da doprinos naučnoj debati na temu potencijalnih kognitivnih prednosti bilingvizma.

Ključne reči: Strupov test sa rečima u boji, kognitivna inhibicija, sukcesivni bilingvizam, srpski, engleski 